\title{
Gastrin and somatostatin in Helicobacter pylori infected antral mucosa
}

\author{
L Ødum, H D Petersen, I B Andersen, B F Hansen, J F Rehfeld
}

\begin{abstract}
Helicobacter pylori infection is associated with increased meal stimulated gastrin secretion, but the reason for this is unknown. Sequence specific radioimmunoassays were used to measure the concentration of $\alpha$-amidated gastrin, the total progastrin product, and somatostatin in biopsy specimens of human antral mucosa. The antral concentrations of $\alpha$-amidated gastrin and of total progastrin products were significantly higher in $H$ pylori infected patients than in those not infected by this organism. In contrast, the antral somatostatin concentration was significantly decreased in infected patients. Progastrin processing, determined by gel chromatography, seemed unaffected by $H$ pylori infection. The results suggest that the finding of increased gastrin secretion from the antral $G$ cells in $H$ pylori infected patients may be a result of reduced inhibition of G-cell secretion by somatostatin.

(Gut 1994; 35: 615-618)
\end{abstract}

Helicobacter pylori infection is associated with increased basal and meal stimulated plasma gastrin concentrations, which become normal after eradication of the bacteria. ${ }^{1-5}$ The reason for the increased gastrin secretion is uncertain. The bacterial production of urease, which might cause an increase in the antral surface $\mathrm{pH}$, does not seem to be involved. ${ }^{5-9}$ Furthermore, the function of the parietal cells seems to be unaffected by chronic $H$ pylori infection, as judged by parietal cell sensitivity to gastrin. ${ }^{10}$

It has recently been suggested that $H$ pylori infection inhibits somatostatin synthesis in the gastric mucosa, as the somatostatin-mRNA concentration decreases. ${ }^{11}$ Decreased somatostatin production reduces the inhibition of gastric secretory functions. ${ }^{12} 13$

Progastrin processing is less complete during permanent $G$ cell hypersecretion in patients with fundic atrophic gastritis than in normal subjects. ${ }^{14}$ In $H$ pylori infected patients, the antral gastrin concentration seems increased, as judged by immunohistochemistry. ${ }^{15}$

The present study aimed to examine the influence of $H$ pylori infection on the antral expression and processing of progastrin and somatostatin. Since $H$ pylori has been shown to inactivate ascorbic acid ${ }^{16}$ and decrease the concentration of vitamin $\mathrm{C}$ in the gastric juice of infected patients, ${ }^{17} 18$ and since ascorbic acid is a cofactor in the amidation of gastrin, ${ }^{19}$ we have also measured antral ascorbic acid and correlated it to the degree of gastrin amidation.

\section{Methods}

SERUM AND ANTRAL MUCOSAL BIOPSY SPECIMENS

Peripheral venous blood and gastroscopic antral biopsy specimens were taken from 32 fasting patients with dyspeptic symptoms. All had given informed written consent. None of the patients had been taking anti-ulcer treatment in the month before the gastroscopy. Blood was kept at $5^{\circ} \mathrm{C}$, and serum was separated within two hours and frozen at $-20^{\circ} \mathrm{C}$ until analysis.

Antral biopsy specimens for measurement of gastrin, somatostatin, and ascorbic acid were frozen within 10 minutes. Tests for urease activity (CLO test, Delta West) were started within five minutes and were performed at $20^{\circ} \mathrm{C}$. The medium was read after one and four hours. A patient was regarded as having $H$ pylori infection if the CLO test was positive or if $H$ pylori could be shown by the histological examination, or both. ${ }^{2021}$ The study was approved by the regional ethical committee.

\section{HISTOLOGICAL EXAMINATION}

Antral biopsy specimens for histological examination were fixed in formalin and routinely processed. Sections were cut at 5-7 $\mu \mathrm{m}$ and were stained with Warthing-Starry silver stain in order to show $H$ pylori-like micro-organisms.

\section{MEASUREMENT OF GASTRIN}

Frozen antral biopsy specimens were immersed directly in boiling water ( $\mathrm{pH} \mathrm{6.6),} 1$ $\mathrm{ml}$ per $\mathrm{mg}$ tissue. Boiling was continued for 20 minutes, after which tissues were homogenised and centrifuged at $10000 \mathrm{~g}$ for 20 minutes. The supernatants were stored at $-20^{\circ} \mathrm{C}$ until assay.

Bioactive $\alpha$-amidated gastrins were measured using antisera 2604 and 2605 . $^{22}$ Antiserum 2604 binds all bioactive gastrins (sulphated as well as non-sulphated) with equimolar potency, whereas the cross reactivity with cholecystokinin is negligible. Antiserum 2605 has similar characteristics but it binds only non-sulphated gastrin.

Total progastrin products were measured after tryptic cleavage of the extracts using antiserum 8017 , specific for the $\mathrm{N}$-terminal 
sequence of human gastrin-17.23 In this way $\mathrm{N}$-terminally extended precursors are cleaved and the N-termini of gastrin-17 exposed to binding to antiserum $8017 .^{24}$ Extracts were incubated with equal volumes of trypsin $(2 \mathrm{mg} / \mathrm{ml}$ in $0.05 \mathrm{M}$ sodium phosphate $\mathrm{pH}$ $7 \cdot 5)$ at $20^{\circ} \mathrm{C}$ for 30 minutes. The enzymatic reaction was terminated by boiling for 30 minutes.

\section{MEASUREMENT OF SOMATOSTATIN}

Frozen tissues were homogenised in four volumes of acid ethanol ${ }^{25}$ and centrifuged at $10000 \mathrm{~g}$ for 20 minutes at $4^{\circ} \mathrm{C}$. The extracts were evaporated, $\mathrm{pH}$ adjusted to $7 \cdot 5$, and centrifuged again and stored at $-20^{\circ} \mathrm{C}$ until analysis. Antisera R 37 directed against the sequence -Cys-Lys-Asn-Phe-Phe- in somatostatin-14 was produced in rabbits as previously described. ${ }^{26}$ Tracer, incubation condition, and separation were as previously described. ${ }^{27}$
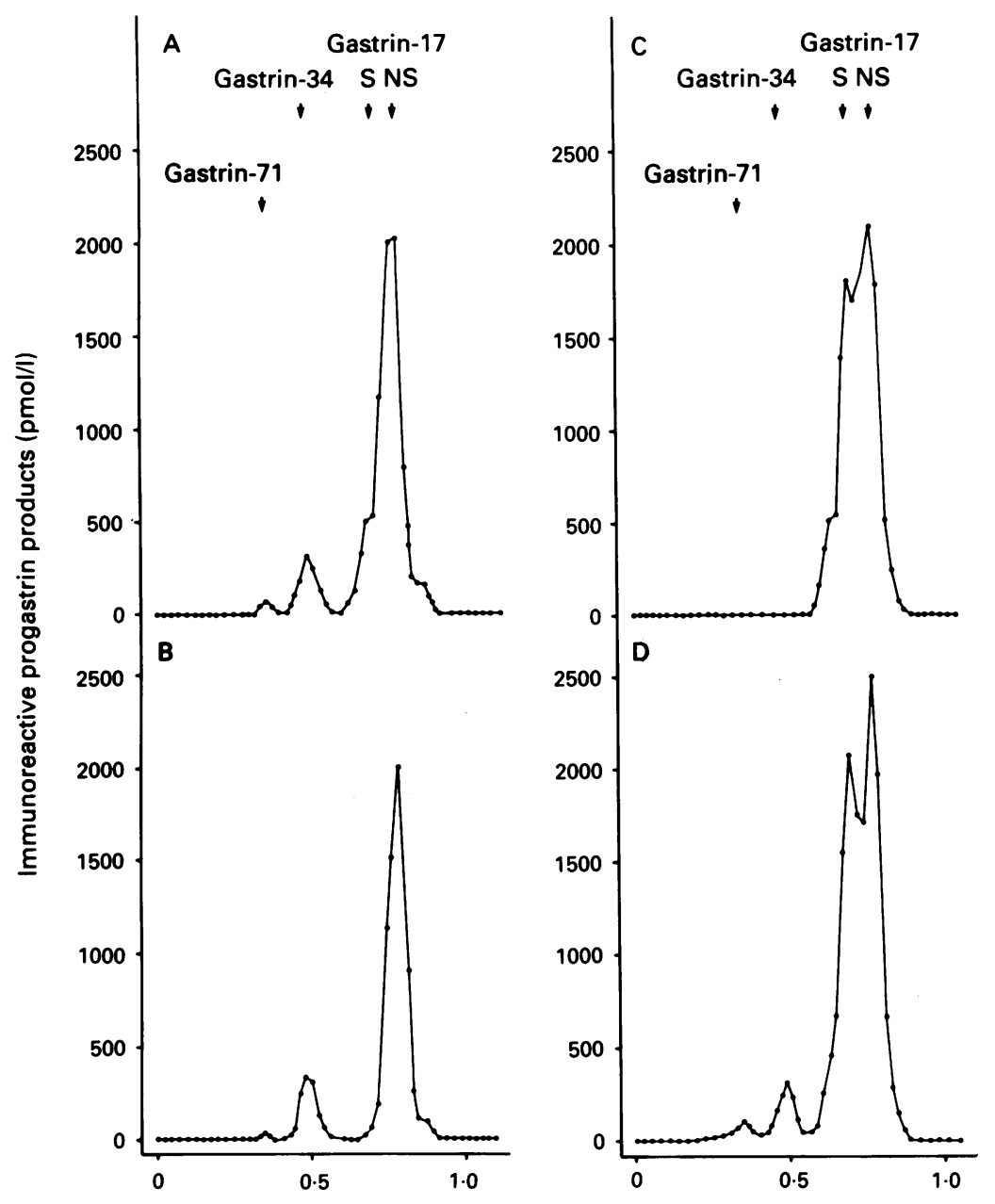

Elution volume $\left(\mathrm{K}_{\mathrm{av}}\right)$

Figure 1:Gel-chromatography of a neutral water extract of an antral mucosal biopsy Figure 1:Gel-chromatography of a neutral water extract of an antral mucosal biopsy
specimen from a Helicobacter pylori infected patient. $(A)$ Shows the elution profile using antiserum 2604 that binds bioactive $\alpha$-amidated gastrins with equimolar potency irrespective of the N-terminal chain length and the degree of tyrosyl O-sulphation. (B) shows the measurements using antiserum 2605, which binds only non-sulphated $\alpha$ amidated gastrins. (C) Shows the elution profile using antiserum 8017, which binds the N-terminus of gastrin 17. Finally, (D) shows the measurements using antiserum 8017 but only after incubation of each fraction with trypsin. Thus, in addition to $\alpha$-amidated gastrin 17 and $C$-terminally extended molecules containing the $N$-terminus of gastrin 17, the measurements in (D) include other progastrin products including gastrin 34.
TABLE I Characteristics of the patients

\begin{tabular}{lrlcl}
\hline $\begin{array}{l}\text { H pylori } \\
\text { status }\end{array}$ & No & $\begin{array}{l}\text { Age (y) } \\
\text { Median (range) }\end{array}$ & $\begin{array}{l}\text { Sex } \\
(F / M)\end{array}$ & $\begin{array}{l}\text { No of patients } \\
\text { with peptic ulcer } \\
\text { duodenallgastric }\end{array}$ \\
\hline $\begin{array}{l}\text { Positive } \\
\text { Negative }\end{array}$ & 9 & $46(32-88)$ & $6 / 3$ & $1 / 3$ \\
& 23 & $57(24-94)$ & $16 / 7$ & $1 / 1$
\end{tabular}

MEASUREMENT OF ASCORBIC ACID

Antral biopsy specimens were homogenised in metaphosphoric acid and ascorbic acid was measured by high performance liquid chromatography combined with electrochemical detection as previously described. ${ }^{28}$ Dehydroascorbic acid was determined after reduction to ascorbic acid. ${ }^{28}$

\section{CHROMATOGRAPHY}

Gel chromatography was performed on Sephadex G-50 (superfine) columns (1 $\mathrm{cm} \times 100 \mathrm{~cm}$ ) that were eluted with $0.125 \mathrm{M}$ ammonium bicarbonate $(\mathrm{pH} 8 \cdot 2)$ at $4^{\circ} \mathrm{C}$ with a flow rate of $4 \mathrm{ml} / \mathrm{h}$ in fractions of $1 \mathrm{ml}$. Void and total volumes of the columns were determined using ${ }^{125} \mathrm{I}$-albumin and ${ }^{22} \mathrm{NaCl}$. The columns were calibrated with gastrin- 17 and gastrin-34.

\section{STATISTICAL ANALYSIS}

The Mann-Whitney $U$ test was used for statistical analysis.

\section{Results}

Characteristics of the patients are shown in Table I. The age, the distribution between male and female, and the number of patients with peptic ulcer did not differ significantly between the two groups. One $H$ pylori negative patient had a duodenal ulcer. This was possibly caused by aspirin taken daily. Only a few patients had duodenal ulcer. They represented a sample of dyspeptic hospital inpatients from a department of medicine.

The concentration of antral bioactive $\alpha$-carboxiamidated gastrin and the total progastrin products were higher in $H$ pylori infected patients than in uninfected patients (Table II). The progastrin processing in the antrum of $H$ pylori infected patients was similar to that in uninfected patients - that is, the antrum contained mainly $\alpha$-amidated gastrin-17 (Figs 1 and 2), except for a reduced tyrosyl O-sulphation of gastrin in the antral extract from one of the $H$ pylori infected patient (Fig 1). The degree of tyrosyl O-sulphation of the $\alpha$ amidated gastrins, as judged by the reactivity

TABLE II Concentration (nmol/g) of mature $\alpha$-amidated gastrin and total progastrin products in antral biopsy specimens from patients with and without Helicobacter pylori infection. Values are median (range)

\begin{tabular}{lrcc}
\hline $\begin{array}{l}\text { H pylori } \\
\text { status }\end{array}$ & No & Amidated gastrin & Total gastrin products \\
\hline Positive & 9 & $13 \cdot 4(6 \cdot 0-32 \cdot 8)$ & $15 \cdot 6(9 \cdot 2-41 \cdot 0)$ \\
Negative & 23 & $4 \cdot 6(0 \cdot 1-29 \cdot 3)^{\star}$ & $8 \cdot 6(0 \cdot 1-32 \cdot 4) \dagger$ \\
\hline
\end{tabular}

Concentrations were significantly increased in $H$ pylori positive compared with negative patients: ${ }^{\star} p=0.005 ; \dagger p=0.011$. 


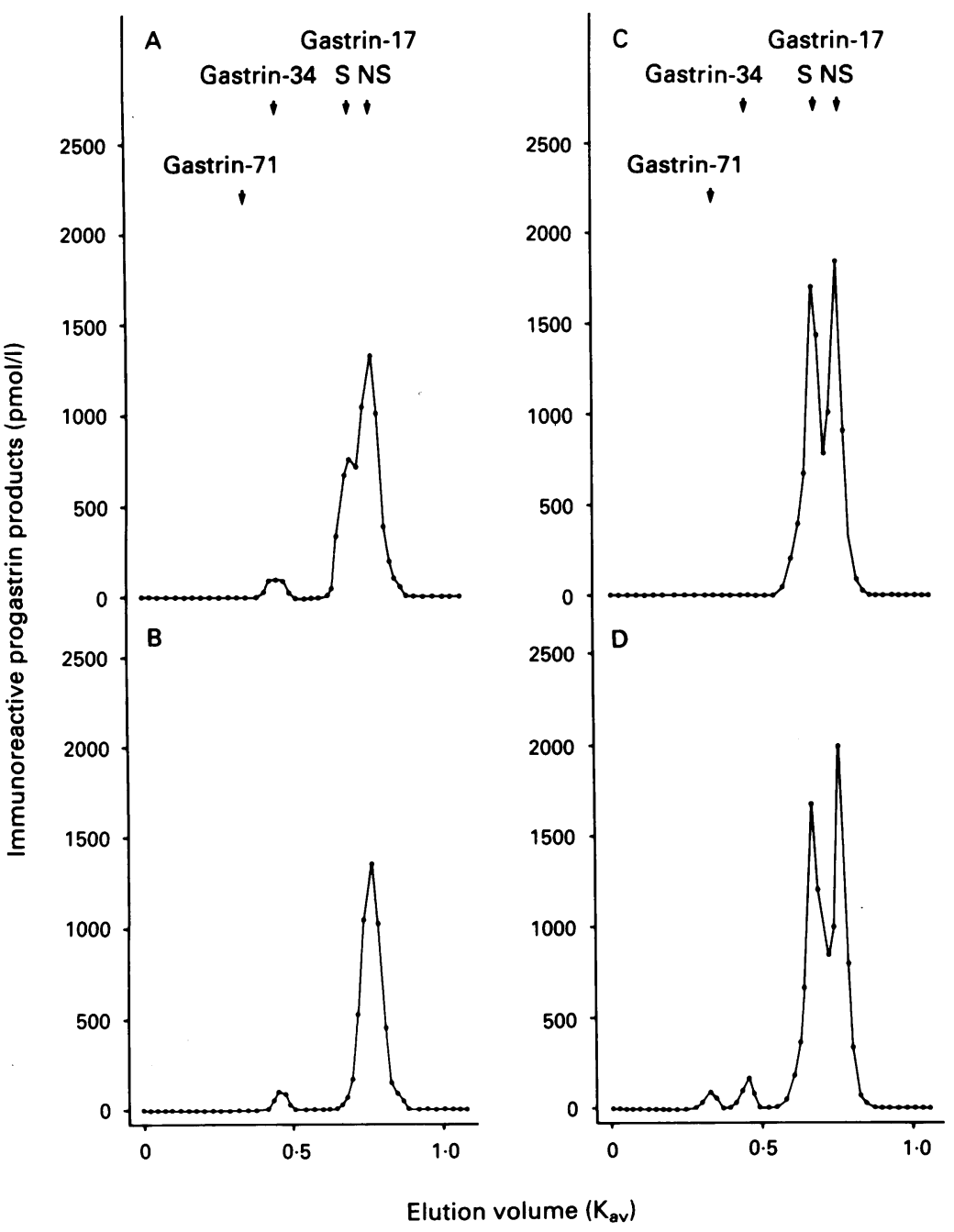

Figure 2: Gel-chromatography of a neutral water extract of an antral biopsy specimen from a patients with dyspepsia, but without Helicobacter pylori infection. The measurements are as described in Figure 1.
TABLE IV Concentration (pmoll) of mature $\alpha$-amidated gastrin and total progastrin products in serum from patients with or without Helicobacter pylori infection. Values are median (range)

\begin{tabular}{lrll}
\hline $\begin{array}{l}\text { H pylori } \\
\text { status }\end{array}$ & No & Amidated gastrin & Total gastrin products \\
\hline Positive & 9 & $20(14-48)$ & $60(50-86)$ \\
Negative & 23 & $21(11-92)$ & $51(12-184)$ \\
\hline
\end{tabular}

not differ between the two groups (Table IV). Furthermore, no correlation could be shown between antral gastrin or somatostatin concentrations and serum gastrin concentrations.

\section{Discussion}

This study shows that the antral content of progastrin and its products is increased in $H$ pylori infected patients. The increase is accompanied by, and perhaps caused by, a corresponding reduction in the antral somatostatin concentration.

The high gastrin concentration in the antrum in patients with $H$ pylori infection (Table II) is in agreement with the results in an immunohistochemical study by Sankey et al, ${ }^{15}$ who showed a more intense immunostaining of G-cells in the presence of $H$ pylori than in uninfected patients.

The increased concentration of bioactive amidated gastrin and of progastrin suggests that the increased concentration is due to an increased gastrin synthesis. This higher synthesis might be due to the inflammation. Thus, tumour necrosis factor $\alpha(\mathrm{TNF}-\alpha)$, found in high concentration in inflamed antrum, ${ }^{29}$ has been shown to increase gastrin gene transcription. ${ }^{30} 31$

The increased meal stimulated gastrin release in $H$ pylori infected patients may simply be due to increased gastrin in the G-cells (Table II). A decreased inhibition of the Gcells by somatostatin may also play a part, as we found a lower antral somatostatin concentration in the infected patients (Table III). This is in agreement with Kaneko et $a l^{32}$ and with Moss et al, ${ }^{11}$ who showed a significant rise in somatostatin-mRNA and in somatostatinimmunoreactive cell density after the eradication of $H$ pylori. Gastrin release is normally inhibited by somatostatin. ${ }^{1213}$ Finally, the inflammation might also affect the gastrin release as $\gamma$-interferon and interleukin-2 stimulates gastrin secretion from dog antrum. ${ }^{33}$

The progastrin processing did not seem to be influenced by $H$ pylori infection. Thus, $H$ pylor infected antrum, like normal antrum, contained mainly amidated G-17. However, tyrosyl O-sulphation of gastrin was decreased in a patient (Fig 1) with a high antral gastrin concentration similar to patients with hypergastrinemia. ${ }^{14}$

The oxidation of ascorbic acid in antral biopsy specimens was low in infected as well as in uninfected patients. The concentration of ascorbic acid was slightly raised in the antrum of infected patients. This could be due to leukocyte infiltration as the ascorbic acid concentration in leukocytes is higher than in the antral mucosa. ${ }^{34}$ droascorbic acid (nmol/g) in antral biopsy specimens from patients with and without Helicobacter pylori infection. Values are median (range)

\begin{tabular}{lrll}
\hline $\begin{array}{l}\text { H pylori } \\
\text { status }\end{array}$ & No & Ascorbic acid & Dehydroascorbic acid \\
\hline Positive & 9 & $1278(1023-2318)$ & $98(28-199)$ \\
Negative & 23 & $1017(500-1983)^{\star}$ & $40(0-420)$ \\
\hline
\end{tabular}

Concentration significantly higher in $H$ pylori positive compared with negative patients: ${ }^{\star} \mathrm{p}=0.03$. 
In conclusion, we showed an increased concentration of gastrin and a decreased concentration of somatostatin in the antral mucosa of $H$ pylori infected patients. The increased meal stimulated gastrin release observed in these patients ${ }^{1-5}$ may be a result of a higher gastrin content of the antral $G$ cells and decreased inhibition by somatostatin.

The skilful technical assistance of Lis Sørensen is gratefully acknowledged.

1 Levi S, Beardshall K, Haddad G, Playford R, Ghosh P, Calam J. Campylobacter pylori and duodenal ulcers: the gastrin link. Lancet 1989; i: 1167-8.

2 Graham DY, Opekun A, Lew GM, Evans DJ, Klein PD, Evans DG. Ablation of exaggerated meal-stimulated gastrin release in duodenal ulcer patients after clearance of Helicobacter (Campylobacter) pylori infection. Gastroenterology 1990; 85: 394-8.

3 McColl KEL, Fullarton GM, Chittajalu R, El Nujumi AM, Macdonald AMI, Dahill SW, et al. Plasma gastrin, daytime intragastric $\mathrm{pH}$, and nocturnal acid output before and at 1 and 7 months after eradication of helicobacter pylori in duodenal

4 Beardshall K, Moss S, Gill J, Levi S, Ghosh P, Playford RJ, Calam J. Suppression of Helicobacter pylori reduces gastrin releasing peptide stimulated gastrin release in duodenal ulcer patients. Gut 1992; 33: 601-3

5 McColl KEL, El Nujumi AM, Dorrian CA, Macdonald AMI, Fullarton GM, Harwood J. Helicobacter pylori and hypergastrinaemia during proton pump inhibitor therapy. Scand F Gastroenterol 1992; 27: 93-8.

6 Chittajallu RS, Neithercut WD, Macdonald AMI, McColl KEL Effect of increasing Helicobacter pylori ammonia production by urea infusion on plasma gastrin concentrations. Gut 1991; 32: 21-4.

7 El Nujumi AM, Dorrian CA, Chittajallu RS, Neithercut WD, McColl KEL. Effect of inhibition of Helicobacter pylori urease activity by acetohydromamic acid on serum pylori urease activity by acetohydromamic acid on serum
gastrin in duodenal ulcer subjects. Gut 1991; 32: 866-70.

8 Chittajallu RS, Dorrian CA, Neithercut WD, Dahill S, McColl KEL. Is Helicobacter pylori associated hypergastrinaemia due to the bacterium's urease activity or the antral gastritis? Gut 1991; 32: 1286-90.

9 Chittajallu RS, Neithercut WD, Ardill JES, McColl KEL. Helicobacter pylori-related hypergastrinaemia is not due to elevated antral surface $\mathrm{pH}$. Scand $\mathcal{f}$ Gastroenterol 1992; 27: $218-22$.

10 Chittajallu RS, Howie CA, McColl KEL. Effect of Helicobacter pylori on parietal cell sensitivity to pentagastrin in duodenal ulcer subjects. Scand $\mathcal{f}$ Gastroenterol gastrin in duodenal

11 Moss SF, Legon S, Bishop AE, Polak JM, Calam J. Effect of Helicobacter pylori on gastric somatostatin in duodenal ulcer disease Lancet 1992; 340: 930-2

12 Brand SJ, Stone D. Reciprocal regulation of antral gastrin and somatostatin gene expression by omeprazole-induced achlorhydria. $\mathcal{F}$ Clin Invest 1988; 82: 1059-66.

$13 \mathrm{Wu} \mathrm{V}$, Sumii K, Tari A, Sumii M, Walsh JH. Regulation of rat antral gastrin and somatostatin gene expression during starvation and after refeeding. Gastroenterology 1991;101: 1552-8.

14 Jensen S. Borch K, Hilsted L, Rehfeld JF. Progastrin processing during antral G-cell hypersecretion in humans. Gastroenterology 1989; 96: 1063-70.
15 Sankey EA, Helliwell PA, Dhillon AP. Immunostaining of antral gastrin cells is quantitatively increased in Helicobacter pylori gastritis. Histopathology 1990; 16: 151-5.

16 Johnson AW, Aleksandrowicz J, Tompkins DS, Rathbone BJ, Losowsky MS. The effect of Campylobacter pylori on ascorbic acid and urea metabolism in vitro. In: Megraud $\mathrm{F}$, Lamouliatte $\mathrm{H}$, eds. Gastroduodenal pathology and Campylobacter pylori. Amsterdam: Elsevier Science Publishers BV, 1989: 405-7.

17 Rathbone BJ, Johnson AW, Wyatt JI, Kelleher J, Heatley RV, Losowsky MS. Ascorbic acid: a factor concentrated RV, Losowsky MS. Ascorbic acid: a factor concentr.

18 Sobala GM, Crabtree JE, Dixon MF, Schorah CJ, Taylor JD, Rathbone BJ, et al. Acute Helicobacter pylori infection: clinical features, local and systemic immune response, gastric mucosal histology, and gastric juice ascorbic acid concentrations. Gut 1991; 32: 1415-8.

19 Hilsted L, Rehfeld JF, Schwartz TW. Impaired $\alpha$-carboxyamidation of gastrin in vitamin $C$-deficient guinea pigs. FEBS Lett 1986; 196: 151-4.

20 Deltenre M, Glupczynski Y, De Prez C, Nyst JF, Burette A, Labbe $M$, et al. The reliability of urease tests, histology and culture in the diagnosis of Campylobacter pylori infection. Scand $\mathcal{f}$ Gastroenterol 1989; 24 (suppl 160): 19-24.

21 McNulty CAM, Dent JC, Uff JS, Gear MWL, Wilkinson SP. Detection of Campylobacter pylori by the biopsy SP. Detection of Campylobacter pylori by the biopsy
urease test: an assessment in 1445 patients. Gut 1989; 30: urease tes

22 Rehfeld JF, Stadil F, Rubin B. Production and evaluation of antibodies for the radioimmune assay of gastrin. Scand $\mathcal{f}$ Clin Lab Invest 1972; 30: 221-32.

23 Bardram L, Rehfeld JF. Production and evaluation of monospecific antibodies for a processing-independent sequence of human progastrin. Scand 7 Clin Lab Invest 1989; 49: 173-82.

24 Rehfeld JF, Bardram L. Processing-independent analysis (PIA) - A new diagnostic tool. Scand $\mathcal{f}$ Clin Lab Invest 1991; 51 (suppl 204): 9-16.

25 Newgard CB, Holst JJ. Heterogeneity of somatostatin like immunoreactivity (SLI) in extracts of porcine, canine and immunoreactivity (SLI) in extracts of porcine, canine and

26 Rehfeld JF. Sequence-specific radioimmunoassays for cholecystokinin, gastrin and somatostatin. Biomedical cholecystokinin, gastrin and
Research 1980; 1 (suppl): $73-8$.

27 Hilsted L, Holst JJ. On the accuracy of radioimmunological determination of somatostatin in plasma. Regulatory Peptides 1982; 4: 13-31.

28 Ødum L. pH optimum of the reduction of dehydroascorbic acid by dithioerytritol. Scand F Clin Lab Invest 1993; 53: 367-71

29 Crabtree JE, Shallcross I, Wyatt JI, Heatley RV. Tumour neurosis factor alpha secretion by Helicobacter pylori colonized gastric mucosa. Gut 1991; 32: 1473-77.

30 Godley JM, Brand SJ. Regulation of the gastrin promoter by epidermal growth factor and neuropeptides. Proc Natl Acad Sci USA 1989; 86: $3036-40$.

31 Merchant JL, Demediuk B, Brand SJ. A GC-rich element confers epidermal growth factor responsiveness to transcription from the gastrin promoter. Mol Cell Biol 1991; 11: $2686-96$

32 Kaneko H, Nakada K, Mitsuma T, Uchida K, Furusawa A, Maeda $\mathrm{Y}$, et al. Helicobacter pylori infection induces a decrease in immunoreactive somatostatin concentration of human stomach. Dig Dis Sci 1992; 37: 409-16.

33 Teichmann RK, Pratschke E, Grab J, Hammer C, Brendel W. Gastrin release by interleukin-2 and $\gamma$-interferon in vitro. Can f Physiol Pharnacol 1986; 64 (suppl): 62.

34 Washko P, Rotrosen D, Levine M. Ascorbic acid in human neutrophils. Am 7 Clin Nutr 1991; 54: 1221S-7S. 